\title{
Impact of Rising Groundwater on Sustainable Irrigated Agriculture in the Command Area of Gadeji Minor, Sindh, Pakistan
}

\author{
GHULAM SHABIR SOLANGI*, ABDUL LATIF QURESHI**, AND MASROOR ALI JATOI*** \\ RECEIVED ON 07.04.2016 ACCEPTED ON 16.08.2016
}

\begin{abstract}
Astudy has been conducted in the command area of Gadeji minor, Sindh, Pakistan to compute the amount of net groundwater recharge and its effect on sustainable irrigated agriculture. In this connection, Water budget equation was used and three groundwater recharging components along with one discharging component were computed for both Rabi and Kharif crop seasons for the period (2001-2013).

Data shows that groundwater is rising at rapid rate during the Kharif season. The percolation rate through cropped fields is the major recharge component; accounting for $81 \%$ in the total mean recharge of 8.42 million $\mathrm{m}^{3}$, moreover the rice area is the major contributor to net groundwater recharge during Kharif season. The contributions of canal seepage and rainfall are estimated to be 16 and $04 \%$ respectively for the above period.

However, during the Rabi season groundwater is rising at low rate where canal seepage is the major recharging component with an average contribution of $48 \%$ in the total mean recharge of 2.32 million $\mathrm{m}^{3}$, the contribution of deep percolation from cropped fields is estimated to be $47 \%$ as compared to the rainfall of only $05 \%$.

Survey shows non-functionality of most of the tubewells, groundwater withdrawal is not sufficient to fully offset groundwater recharge which has increased water table and caused waterlogging and soil salinity in more than $\mathbf{4 0 \%}$ of agricultural land. To overcome this rising water table problem, it is recommended: to change existing cropping pattern (i.e. minimize or no cultivation of rice crop), lining of minor and all its watercourses, adopt salt tolerant crops and increase groundwater withdrawals by operating tubewells on emergency basis.
\end{abstract}

Key Words: Groundwater Recharge, Waterlogging, Gadeji Minor, Rohri Canal, Pakistan.

\section{INTRODUCTION}

W ater is a natural bounty; it can be utilized to serve a variety of functions. Proper usage of water may nourish our fields and forests. Actually, it is a resource which plays leading role in over all prosperity of a nation and entire community as a whole. But, if it is not planned properly, that same may become wild in the shape of harsh storms, floods, and bringing disasters [1].

\footnotetext{
* Department of Civil Engineering, Mehran University of Engineering \& Technology, Shaheed Zulfiqar Ali Bhutto Campus, Khairpur Mir's.

** US-Pakistan Centres for Advanced Studies in Water, Mehran University of Engineering \& Technology, Jamshoro.

*** Department of Civil Engineering, Mehran University of Engineering \& Technology, Jamshoro.
}

Mehran University Research Journal of Engineering \& Technology, Volume 36, No. 1, January, 2017 [p-ISSN: 0254-7821, e-ISSN: 2413-7219] 
Water is the major limiting factor for crop production in arid and semi-arid areas [2-5]. The direct as well as storage irrigation schemes require a network of irrigation channels. Rohri canal is longest canal in Pakistan, off-takes from the left flank of Sukkur Barrage. Rohri canal is bifurcated into branches covering the major area to be irrigated in Sindh. Gadeji minor is also one of them which off-takes from right side of Rohri canal at its head reach at RD 204.

Sindh province is located in a subtropical region which is hot in summer and cold in winter. The annual rainfall averages about 6-7" (15-18 cm), falling mainly during July and August. Because of low and uncertain annual rainfall, supplemental irrigation is mainly used to fulfil crop water requirements. Due to seepage from canal irrigation system and over irrigation, waterlogging and soil salinity has also been increased [6-7]. So is the case with Gadeji minor which is badly affected by waterlogging and soil salinity, hence it is selected to study its causes and suggest the remedies.

Due to waterlogging and soil salinity, the quality of soil and crop productivity is reduced [8-10]. This twin problem is spreading more in those areas, which are irrigated by canal irrigation system and creates hydrologic imbalances.
Agricultural land of Pakistan of 4.465 Million hectares $(31.7 \%)$ is predominant, primarily because of extensive canal irrigation system which was developed through history i.e. large expansion during British and postindependence period. Sindh has 294.3 thousand hectares of area (i.e. $2.1 \%$ ) waterlogged which is no longer suitable for crop production due to rise of groundwater. In this paper, water budget equation for the study area has been used to compute net groundwater recharge considering rainfall, seepage from canal, field percolation and groundwater extraction. In addition to above, field survey has also been conducted through questionnaire and interviews from farmers to determine the ground realities. Based on results and discussions conclusions and suggestions are made to improve the crop productivity of the study area.

\section{THE STUDY AREA}

\subsection{Location}

Gadeji minor is an irrigation channel located in district Khairpur (Mir's), Sindh having average reduced level of $33 \mathrm{~m}$ and geographic co-ordinates as $27^{\circ} 15^{\prime} 15^{\prime \prime} \mathrm{N}$ (latitude) and $68^{\circ} 28^{\prime} 50^{\prime \prime} \mathrm{E}$ (longitude). The study area location in Google map is shown in Fig. 1; however, salient features of the minor are described in Table 1.

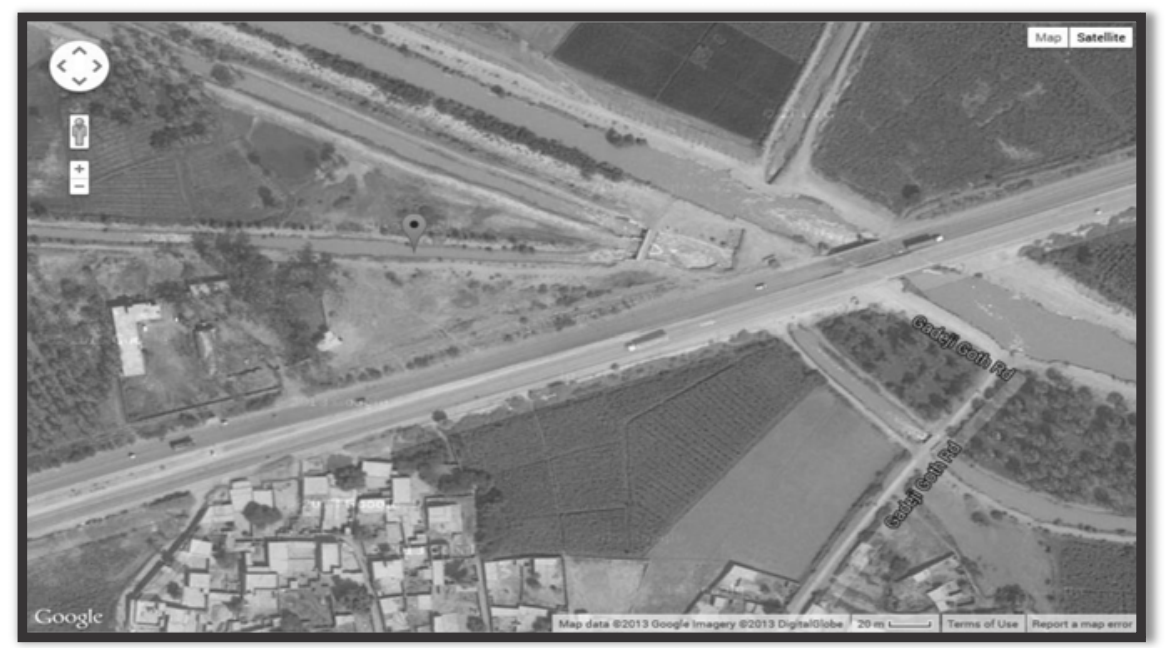

FIG. 1. LOCATION OF GADEJI MINOR IN THE GOOGLE MAP

Mehran University Research Journal of Engineering \& Technology, Volume 36, No. 1, January, 2017 [p-ISSN: 0254-7821, e-ISSN: 2413-7219] 


\subsection{Cropping Pattern}

There are two cropping seasons i.e. Rabi and Kharif in the study area. In Rabi, wheat is the major crop and in Kharif cotton and rice are the major crops. Whereas, sugarcane, vegetables and orchards, such as mangoes, khajoor, bananas, lemons, etc as perennial crops are also grown in the command area of Gadeji minor.

\section{MATERIALS AND METHOD}

The water budget equation has been used to compute the amount of net groundwater recharge [11] in the command area of the Gadeji minor. The water budget is the change in storage i.e. net groundwater recharge, which is described as follows:

\pm Change in storage $=$ Mass inflow - Mass out flow

In the present study, Equation (1,) may be rewritten as:

\pm Change in storage $=$ Recharge from rainfall $\left(R_{r}\right)$

+ Recharge from canal seepage $\left(\mathrm{R}_{\mathrm{c}}\right)$

+ Recharge from field percolation $\left(\mathrm{R}_{\mathrm{p}}\right)$

- Extraction of groundwater withdrawal through tube wells/ open wells $\left(\mathrm{Q}_{\mathrm{w}}\right)$

TABLE 1. SALIENT FEATURES OF GADEJI MINOR

\begin{tabular}{|c|c|c|}
\hline No. & Salient Feature & Data \\
\hline 1. & Name of parent channel & Main Rohri Canal \\
\hline 2. & RD takes off & 204 \\
\hline 3. & Design discharge (cusecs) & 22.86 \\
\hline 4. & Gross commanded area (acres) & 4,425 \\
\hline 5. & Culturable command area (acres) & 4,415 \\
\hline 6. & Total length of Gadeji Minor (irrigation & 4.54 \\
\hline 7. & Total length of Gadeji Minor (R.Ds) & 22.7 \\
\hline 8. & FSL at Head of the minor (ft) & 162.0 \\
\hline 9. & FSL at Tail of the minor (ft) & 158.22 \\
\hline 10. & No. of off- taking watercourses (L/S) & 13 \\
\hline 11. & No. of off-taking watercourses (R/S) & 11 \\
\hline \multicolumn{3}{|c|}{ Source: Irrigation West Division Khairpur Mir's } \\
\hline
\end{tabular}

\subsubsection{Groundwater Recharge from Rainfall}

Amount of groundwater recharge from rainfall in irrigated areas has been estimated using following formula:

$\mathrm{R}_{\mathrm{r}}=$ Area of irrigated fields $(A) \times$ total rainfall $\left(\mathrm{R}_{\mathrm{t}}\right) \times 20 \%$

For estimating recharge from rainfall in irrigated areas, $20 \%$ of the total rainfall (i.e. 0.2 ) contributes groundwater. The balance $(80 \%)$ is assumed to be intercepted by the crop, stored as soil water or removed as surface runoff [12-13].

For this study, rainfall data observed at nearest gauge station has been collected from Climate Data Processing Centre, Pakistan Meteorological Department Karachi for the period of 12 years. Figs. 2-3 shows the graphical representation of observed rainfall during Rabi and Kharif seasons in the study area.

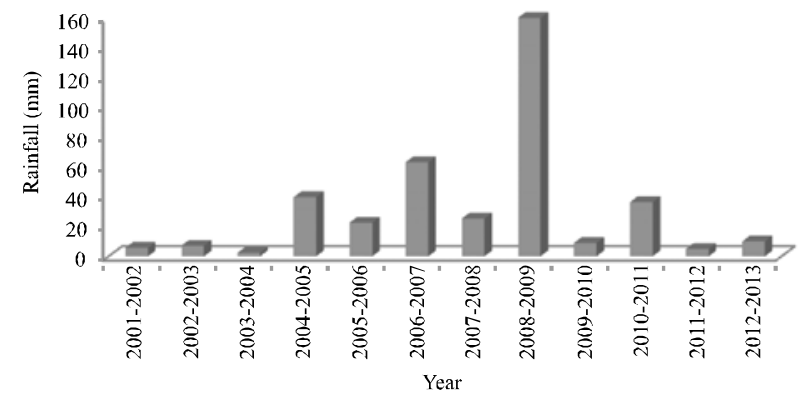

FIG. 2. GRAPHICAL REPRESENTATION OF TOTAL AMOUNT OF OBSERVED RAINFALL DURING RABI SEASON (Million $\mathrm{m}$ )

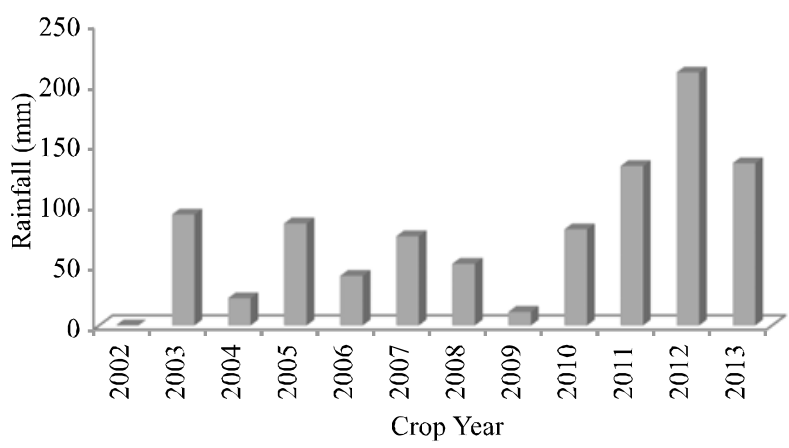

FIG. 3. GRAPHICAL REPRESENTATION OF TOTAL AMOUNT OF OBSERVED RAINFALL DURING KHARIF SEASON (Million $\mathrm{m}$ )

Mehran University Research Journal of Engineering \& Technology, Volume 36, No. 1, January, 2017 [p-ISSN: 0254-7821, e-ISSN: 2413-7219] 


\subsubsection{Groundwater Recharge from Canal Seepage}

Seepage from the studied minor is one of the major contributors towards groundwater recharge. This recharge from minor seepage in the study area has been observed using following formula [14].

$\mathrm{R}_{\mathrm{c}}=\mathrm{L} \times \mathrm{P} \times \mathrm{N}_{\mathrm{d}} \times \mathrm{SF} \times 86400$

Where $\mathrm{R}_{\mathrm{c}}$ is groundwater recharge due to canal/minor seepage $\left(\mathrm{m}^{3}\right), \mathrm{L}$ is length of canal/minor $(\mathrm{m}), \mathrm{P}$ is wetted perimeter of canal/minor $(\mathrm{m}), \mathrm{N}_{\mathrm{d}}$ is number of running days of the canal/minor during the season (day), and SF is seepage factor for the canal/minor (cumec/10 $10^{6}$ sq.m of wetted area).

Average number of running days of the Gadeji minor during Rabi and Kharif seasons are 145 and 150 respectively.

Literature shows that for unlined channels, the value of SF be taken as 2.5-3.0 cumec $/ 10^{6}$ sq.m of wetted area [12].

\subsubsection{Groundwater Recharge from Irrigated Fields}

In the command area of Gadeji minor, groundwater recharge from irrigated environments has been estimated using following formula (Guidelines suggested by the Groundwater Estimation Committee, Ministry of India [15].

$\mathrm{R}_{\mathrm{p}}=\mathrm{A} \times \mathrm{D} \times \mathrm{D}_{\mathrm{f}}$

Where $\mathrm{R}_{\mathrm{p}}$ is groundwater recharge due to field percolation $\left(\mathrm{m}^{3}\right)$, A is area under crop cultivation $\left(\mathrm{m}^{2}\right), \mathrm{D}$ is depth of irrigation water applied to the field $(\mathrm{m}), \mathrm{D}_{\mathrm{f}}$ is fraction of applied water contributed as ground water recharge. Fraction of applied water $\left(D_{f}\right)$ values used for different crops cultivated in the command area of studied minor are described in Table 2.

\subsubsection{Extraction of Groundwater through Tubewells}

From field survey of command area of Gadeji minor and interviews with farmers of shallow and deep tubewells

and keeping in view the literature regarding tubewell withdrawls $[12,14]$ the seasonal tubewell withdrawals have been estimated at the rate of $7,250 \mathrm{~m}^{3}$ for shallow tubewells, while $75,000 \mathrm{~m}^{3}$ for deep tube wells Table 3 .

TABLE 2. FRACTION OF APPLIED WATER (D ${ }_{\text {F }}$ VALUES USED FOR DIFFERENT CROPS CULTIVATED IN THE COMMAND AREA OF STUDIED MINOR

\begin{tabular}{|c|c|c|}
\hline No. & Kind of Crop & Value (Df) \\
\hline 1. & Wheat & 0.056 \\
\hline 2. & Grams & 0.056 \\
\hline 3. & Sugarcane & 0.18 \\
\hline 4. & Fodder & 0.312 \\
\hline 5. & Banana & 0.2 \\
\hline 6. & Vegetables & 0.16 \\
\hline 7. & Gardens & 0.22 \\
\hline 8. & Cotton & 0.14 \\
\hline 9. & Rice & 0.59 \\
\hline 10. & Jowar & 0.312 \\
\hline 11. & Sugarcane & 0.18 \\
\hline 12. & Banana & 0.2 \\
\hline 13. & Vegetables & 0.16 \\
\hline
\end{tabular}

TABLE 3. NUMBER OF FUNCTIONAL TUBE WELLS IN THE COMMAND AREA OF GADEJI MINOR

\begin{tabular}{|c|c|c|c|c|c|}
\hline \multicolumn{3}{|c|}{ Rabi Season } & \multicolumn{3}{|c|}{ Kharif Season } \\
\hline Year & $\begin{array}{c}\text { No. } \\
\text { of Shallow } \\
\text { TWs }\end{array}$ & $\begin{array}{c}\text { No. } \\
\text { of Deep } \\
\text { TWs }\end{array}$ & Year & $\begin{array}{c}\text { No. of } \\
\text { Shallow } \\
\text { TWs }\end{array}$ & $\begin{array}{c}\text { No. } \\
\text { of Deep } \\
\text { TWs }\end{array}$ \\
\hline 2000-2001 & 60 & 6 & 2001 & 55 & 6 \\
\hline $2001-2002$ & 58 & 6 & 2002 & 58 & 6 \\
\hline $2002-2003$ & 59 & 5 & 2003 & 56 & 5 \\
\hline $2003-2004$ & 60 & 4 & 2004 & 44 & 4 \\
\hline $2004-2005$ & 45 & 4 & 2005 & 3 & 4 \\
\hline $2005-2006$ & 2 & 4 & 2006 & 2 & 4 \\
\hline $2006-2007$ & 2 & 4 & 2007 & 1 & 4 \\
\hline $2007-2008$ & 1 & 4 & 2008 & 2 & 4 \\
\hline $2008-2009$ & 1 & 4 & 2009 & 1 & 4 \\
\hline $2009-2010$ & 3 & 4 & 2010 & 2 & 4 \\
\hline $2010-2011$ & 2 & 4 & 2011 & 2 & 4 \\
\hline $2011-2012$ & 3 & 4 & 2012 & 3 & 4 \\
\hline $2012-2013$ & 2 & 5 & 2013 & 4 & 4 \\
\hline & & & & & \\
\hline
\end{tabular}

Mehran University Research Journal of Engineering \& Technology, Volume 36, No. 1, January, 2017 [p-ISSN: 0254-7821, e-ISSN: 2413-7219] 
The calculations of recharge and discharge from different sources as stated above have been described in Tables 4-5.

\subsection{Effect of Groundwater Rise}

In order to evaluate the effect of groundwater rise on irrigated agriculture in the command area of the studied minor, watercourse wise detailed survey and interviews were made in order to collect data regarding: waterlogged area and crop yield of main crops grown in the study area for different crop crops was made. The detailed analysis of the survey regarding above two main parameters are described in section 5 .

\section{RESULTS AND DISCUSSION}

\subsection{Net Groundwater Recharge}

Net groundwater recharge in the command area of Gadeji minor has been calculated as the sum of the three recharging components as stated above in section 3 . These net recharges for Rabi and Kharif are expressed in Tables 4-5 respectively along with their graphs (Figs. 4-5).

From Table 5, i.e. in the Kharif season, it is observed that deep percolation rate through cropped fields is the major recharging component that is accounting for about $81 \%$ (i.e. 6.78 million $\mathrm{m}^{3}$ ) of the total mean recharge of 8.12 million $\mathrm{m}^{3}$. That may be because of cultivation of rice crop in the study area. The amount of deep percolation through cropped fields is more than double of total mean recharge during Rabi season. However, extraction of groundwater during both seasons is not enough to fully counteract groundwater recharge from other sources.

\subsection{Groundwater Rise}

The net groundwater recharge shows a mean recharge of 2.32 and 8.12 million $\mathrm{m}^{3}$ for Rabi and Kharif seasons respectively that has resulted the groundwater rise in the command area of studied minor. In order to verify this groundwater mounting rate, depth to water table data

TABLE 4. SUMMARY OF NET GROUNDWATER RECHARGES COMPONENTS DURING RABI SEASON (Million $\mathrm{m}^{3}$ )

\begin{tabular}{|c|c|c|c|c|c|c|c|}
\hline No. & Crop Year & Rainfall & Canal Seepage & Deep Percolation & Total Recharge & $\begin{array}{c}\text { Extraction through } \\
\text { Tubewells }\end{array}$ & Net Recharge \\
\hline 1. & $2001-2002$ & 0.02 & 1.03 & 1.36 & 2.41 & 0.70 & 1.71 \\
\hline 3. & $2002-2003$ & 0.03 & 1.19 & 1.33 & 2.55 & 0.65 & 1.90 \\
\hline 3. & $2003-2004$ & 0.01 & 1.25 & 1.32 & 2.58 & 0.62 & 1.96 \\
\hline 4. & $2004-2005$ & 0.14 & 1.27 & 1.32 & 2.73 & 0.51 & 2.22 \\
\hline 5. & $2005-2006$ & 0.08 & 1.32 & 1.24 & 2.64 & 0.19 & 2.45 \\
\hline 6. & $2006-2007$ & 0.23 & 1.35 & 1.25 & 2.83 & 0.19 & 2.64 \\
\hline 7. & $2007-2008$ & 0.09 & 1.24 & 1.26 & 2.59 & 0.18 & 2.41 \\
\hline 8. & $2008-2009$ & 0.57 & 1.37 & 1.17 & 3.11 & 0.19 & 2.92 \\
\hline 9. & $2009-2010$ & 0.03 & 1.35 & 1.23 & 2.61 & 0.20 & 2.41 \\
\hline 10. & $2010-2011$ & 0.13 & 1.25 & 1.20 & 2.58 & 0.19 & 2.39 \\
\hline 11. & $2011-2012$ & 0.02 & 1.37 & 1.18 & 2.57 & 0.20 & 2.37 \\
\hline 12. & $2012-2013$ & 0.15 & 1.35 & 1.14 & 2.64 & 0.24 & 2.40 \\
\hline
\end{tabular}

Mehran University Research Journal of Engineering \& Technology, Volume 36, No. 1, January, 2017 [p-ISSN: 0254-7821, e-ISSN: 2413-7219] 
was collected from IWASRI (International Waterlogging and Salinity Reclamation Institute), WAPDA, Lahore, for Khairpur Mir's command area for the period of 2008-2011. The average depth to water table data of some selected GPS coordinates in and around the command area of Gadeji minor has been calculated and is shown in Fig. 6.

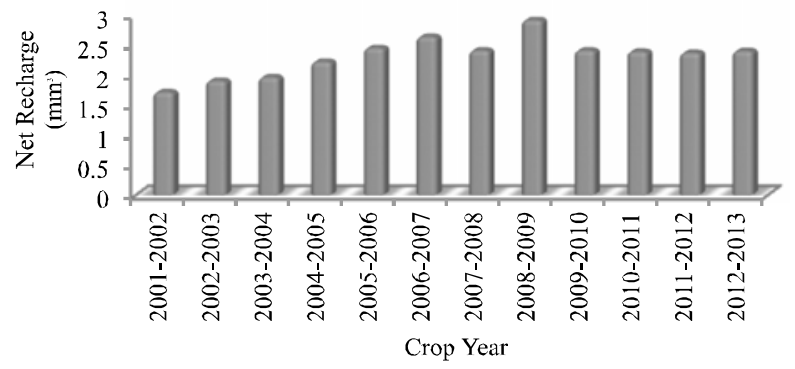

FIG. 4. GRAPHICAL REPRESENTATION OF NET GROUNDWATER RECHARGE DURING RABI SEASON

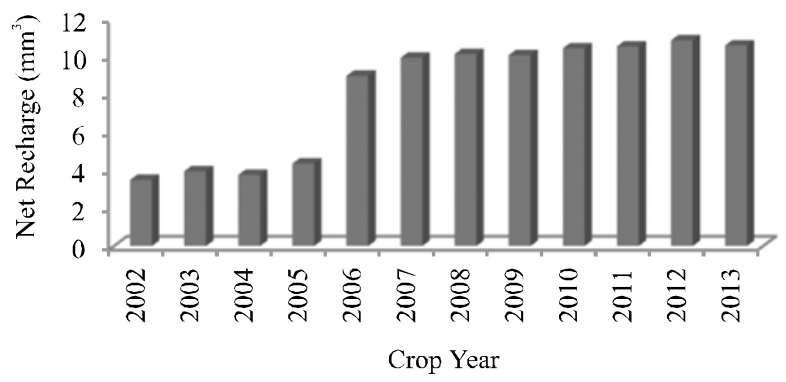

(Million $\mathrm{m}^{3}$ )

FIG. 5. GRAPHICAL REPRESENTATION OF NET GROUND WATER RECHARGE DURING KHARIF SEASON (Million $\mathrm{m}^{3}$ )

\subsection{Detailed Survey/Effect of Groundwater Rise}

In order to observe the effect of rising groundwater on the agricultural land of the studied minor, detailed survey i.e. watercourse wise observation of waterlogged area was made (Table 6). That survey report shows that 1796 acres (i.e. $41 \%$ ) out of 4425 acres is highly waterlogged. Furthermore, in watercourse No. 1-R, the waterlogged area is maximum (i.e. 85\%) whereas in watercourse No. 13-R, the affected area is minimum (i.e. 14\%). Interviews with farmers/land owners were also conducted to collect the data of crop yield for different years. This data was collected randomly from 12 sample farmers out of 108 farmers.

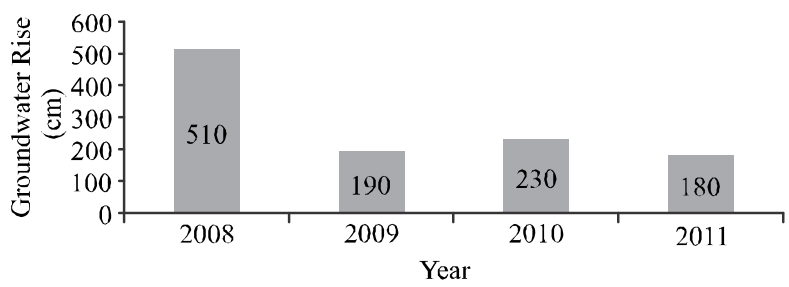

FIG. 6. VARIATION OF AVERAGE DEPTH TO WATER TABLE AT VARIOUS GPS CO-ORDINATES IN/NEAR GADEJI MINOR COMMAND AREA

TABLE 5. SUMMARY OF NET GROUNDWATER RECHARGES COMPONENTS DURING KHARIF SEASON (Million $\mathrm{m}^{3}$ )

\begin{tabular}{|c|c|c|c|c|c|c|c|}
\hline No. & Crop Year & $\begin{array}{c}\text { Recharge from } \\
\text { Rainfall }\end{array}$ & $\begin{array}{c}\text { Recharge from } \\
\text { Canal Seepage }\end{array}$ & $\begin{array}{c}\text { Recharge from } \\
\text { Cropped Fields }\end{array}$ & Total Recharge & $\begin{array}{c}\text { Extraction through } \\
\text { Tubewells }\end{array}$ & \begin{tabular}{c} 
Net Recharge \\
\hline 1.
\end{tabular} \\
\hline 3. & 2002 & $\tilde{N}-$ & 1.20 & 3.00 & 4.20 & 0.69 & 3.51 \\
\hline 3. & 2004 & 0.33 & 1.29 & 2.98 & 4.60 & 0.63 & 3.97 \\
\hline 4. & 2005 & 0.08 & 1.23 & 2.97 & 4.28 & 0.50 & 3.78 \\
\hline 5. & 2006 & 0.15 & 1.40 & 2.88 & 4.59 & 0.21 & 4.38 \\
\hline 6. & 2007 & 0.27 & 1.46 & 8.31 & 10.14 & 0.18 & 9.19 \\
\hline 7. & 2008 & 0.18 & 1.40 & 8.77 & 10.35 & 0.19 & 10.16 \\
\hline 8. & 2009 & 0.04 & 1.32 & 8.93 & 10.29 & 0.19 & 10.10 \\
\hline 9. & 2010 & 0.29 & 1.39 & 8.97 & 10.65 & 0.19 & 10.46 \\
\hline 10. & 2011 & 0.47 & 1.42 & 8.86 & 10.75 & 0.19 & 10.56 \\
\hline 11. & 2012 & 0.75 & 1.40 & 8.95 & 11.10 & 0.21 & 10.89 \\
\hline 12. & 2013 & 0.48 & 1.46 & 8.88 & 10.82 & 0.20 & 10.62 \\
\hline
\end{tabular}

Mehran University Research Journal of Engineering \& Technology, Volume 36, No. 1, January, 2017 [p-ISSN: 0254-7821, e-ISSN: 2413-7219] 
TABLE 6. WATERCOURSE WISE WATERLOGGED AREA IN THE COMMAND AREA OF GADEJI MINOR

\begin{tabular}{|c|c|c|c|c|}
\hline No. & $\begin{array}{c}\text { Watercourse } \\
\text { No. }\end{array}$ & $\begin{array}{c}\text { Gross } \\
\text { Commanded } \\
\text { Area (Acres) }\end{array}$ & $\begin{array}{l}\text { Waterlogged } \\
\text { Area (Acres) }\end{array}$ & $\begin{array}{c}\text { Waterlogged } \\
\text { Area }(\%)\end{array}$ \\
\hline 1. & $1 \mathrm{R}$ & 53 & 45 & 85 \\
\hline 2. & $2 \mathrm{~L}$ & 58 & 30 & 52 \\
\hline 3. & $3 \mathrm{~L}$ & 266 & 150 & 56 \\
\hline 4. & $4 \mathrm{R}$ & 124 & 101 & 81 \\
\hline 5. & $5 \mathrm{~L}$ & 146 & 94 & 64 \\
\hline 6. & $5 \mathrm{AL}$ & 121 & 95 & 79 \\
\hline 7. & $5 \mathrm{BL}$ & 158 & 58 & 37 \\
\hline 8. & $6 \mathrm{R}$ & 162 & 60 & 37 \\
\hline 9. & $6 \mathrm{AR}$ & 258 & 60 & 23 \\
\hline 10. & $6 \mathrm{BR}$ & 114 & 50 & 44 \\
\hline 11. & $7 \mathrm{~L}$ & 125 & 40 & 32 \\
\hline 12. & $8 \mathrm{R}$ & 155 & 70 & 45 \\
\hline 13. & $9 \mathrm{~L}$ & 125 & 50 & 40 \\
\hline 14. & $10 \mathrm{~L}$ & 233 & 190 & 82 \\
\hline 15. & $11 \mathrm{R}$ & 385 & 89 & 23 \\
\hline 16. & $12 \mathrm{~L}$ & 94 & 40 & 43 \\
\hline 17. & $13 \mathrm{R}$ & 211 & 30 & 14 \\
\hline 18. & $14 \mathrm{R}$ & 234 & 60 & 26 \\
\hline 19. & $15 \mathrm{R}$ & 350 & 57 & 16 \\
\hline 20. & $16 \mathrm{~L}$ & 265 & 90 & 34 \\
\hline 21. & $17 \mathrm{~L}$ & 200 & 63 & 32 \\
\hline 22. & $18 \mathrm{~L}$ & 233 & 105 & 45 \\
\hline 23. & $19 \mathrm{~T}$ & 248 & 108 & 44 \\
\hline 24. & $20 \mathrm{~T}$ & 107 & 61 & 57 \\
\hline \multicolumn{2}{|c|}{ Total } & 4425 & 1796 & 41 \\
\hline
\end{tabular}

\section{CONCLUSIONS}

Based on the computations of net groundwater recharge considering rainfall, seepage from canal, field percolation and groundwater extraction and field survey through questionnaire and interviews from farmers, following conclusions are made:

The net groundwater recharge in the command area of Gadeji minor comes 2.32 and 8.12 million $\mathrm{m}^{3}$ for Rabi and Kharif seasons respectively. The deep percolation rate through cropped fields in Kharif season is the major recharging component which accounts for about $81 \%$ (i.e. 6.78 million $\mathrm{m}^{3}$ ) of the total seasonal recharge of 8.12 million $\mathrm{m}^{3}$. This may be because of cultivation of rice crop in the study area.
This rise of groundwater has created water logging situation in the command area of studied minor. Survey shows that 1796 acres out of 4425 acres are waterlogged i.e. $41 \%$ of Gross command area. The maximum waterlogged area of $85 \%$ was observed at the head reach of watercourse No. 1-R.

Survey shows that most of tubewells are non-functional; hence groundwater withdrawal is not sufficient to fully offset groundwater recharge from other sources that has caused the twin problem of waterlogging and soil salinity in more than $40 \%$ of agricultural land. Hence, the agriculture of the study area is badly affected.

Initially, the Gadeji minor was at the extreme end of Abul wah which is off taking from Khairpur Feeder West. Due to its position on extreme end, it always remained deficient. The abadgars of Gadeji minor had agitated for shortage of water. Hence, its head was shifted during the year 2003 to 2004. Now, it is taking-off water directly from main Rohri canal. As a result of more water reached in the minor, the cultivation of rice crop has been increased from 240 acres in 2001 to 1390 acres after 2005. Df value for rice crop is $59 \%$ i.e. more as compared to all other crops. Hence, a sudden change has been observed in the net groundwater recharge in the command area of studied minor.

The groundwater level is rising continuously in the command area of Gadeji minor; which has been verified with the observations of piezometers on some readings collected from IWASRI.

Before 2005, average per acre yield of wheat crop was up to 50 mounds, but now it has declined to average of 18 mounds. Similarly, yield of cotton crop has declined down to 15 mounds which were 45 mounds in the period of 2000-2005.

\section{SUGGESTIONS}

Based on conclusions, following suggestions are made:

(i) Cultivators/farmers may be motivated to use surface and groundwater conjunctively and to reduce over irrigation.

(ii) To reduce conveyance losses at field, the minor and its watercourses may be lined. 
(iii) In the command area, where there is salinity, salt tolerant varieties of crops be cultivated as well as crop rotation should be introduced.

(iv) Percolation rates in the command area of the minor can be reduced by reducing cultivation of rice crop.

(v) In order to maintain equilibrium of replenishment and depletion, all non-functional tubewells should be made functional on emergency basis.

\section{ACKNOWLEDGEMENTS}

Authors are grateful to Institute of Water Resources Engineering \& Management, Mehran University of Engineering \& Technology, Jamshoro, Pakistan, for providing logistic support for conducting this study. Authors also extend their gratitude to Mr. Ali Gul Phul, SDO, Mr. Khadim Hussain Gilal, Sub Engineer, Irrigation $\&$ Power Department West Division, Khairpur Mir's, Engr. Tahir Hussain Mughal, NPIW, FT Sobhodero and Mr. Nadeem Faisal, Deputy Director, Climate Data Processing Centre, Pakistan Meteorological Department, Karachi for providing necessary data regarding this study.

\section{REFERENCES}

[1] Garg, S.K., "Hydrology and Water Resources Engineering", Hand book, Khanna Publishers, India, 2012.

[2] Jalota, S.K., and Arora, V.K., "Model-Based Assessment of Water Balance Components under Different Cropping Systems in North-West India", Journal of Agricultural Water Management, Volume 57, pp. 75-87, 2002.

[3] Li, Z.Z., Li, W.D., and Li, W.L., "Dry Period Irrigation and Fertilizer Application Affect Water Use and Yield of Spring Wheat in Semi-Arid Regions", Journal of Agricultural Water Management, Volume 65, pp. 133-143, India, 2004.

[4] Ji, X.-B. Kang, E.-S., and Chen, “A Mathematical Model for Simulating Water Balances in Cropped Sandy Soil with Conventional Flood Irrigation Applied", Journal of Agricultural Water Management, Volume 87, pp. 337-247, India, 2007.
Zeleke, K.T., Luckett, D., and Cowley, R., "Calibration and Testing of the FAO Aqua Crop Model for Canola", Journal of Agronomy, Volume 103, No. 6, pp. 1610-1618, 2011.

[6] Kumar, R., and Singh, J., "Regional Water Management Modeling for Decision Support in Irrigated Agriculture", Journal of Irrigation Drainage Engineering, Volume 129, No. 6, pp. 432-439, 2003.

[7] Wichelns, D., and Oster, J.D., "Sustainable Irrigation is Necessary and Achievable, But Direct Costs and Environmental Impacts can be Substantial", Journal of Agricultural Water Management, Volume 86, pp. 114-127, India, 2006.

[8] Upadhyaya, A., and Chauhan, H.S., "Water Table Rise in Sloping Aquifer Due to Canal Seepage and Constant Recharge", Journal of Irrigation \& Drainage Engineering ASCE, Volume 128, No. 3, pp. 160-167, 2002.

[9] Oster, J.D., and Wichelns, D., "Economic and Agronomic Strategies to Achieve Sustainable Irrigation", Journal of Irrigation Science, Volume 22, No. 3-4, pp.107-120, 2003.

[10] Sharma, P.D., and Tyagi, N.K., "On Farm Management of Saline Drainage Water in Arid and Semi-Arid Regions", Journal of Irrigation Drainage System, Volume 53, No. 1, pp. 87-103, 2004.

[11] Singh, A., Krause, P, Panda, S.N., and Flugel, W.A., "Rising Water Table: A Threat to Sustainable Agriculture in an Irrigated Semi-Arid Region of Haryana, India", Journal of Agricultural Water Management, Volume 97, pp 1443-1451, India, 2010.

[12] Gupta, M.C., "Studies for the Use of Saline Water in the Command Areas of Irrigation Projects, Haryana, India", Groundwater Balance, HSMITC Report, Working Document, 1.6, 1983.

[13] Singh, R., Sondhi, S.K., Singh, J., and Kumar, R., "A Groundwater Model for Simulating the Rise of Water Table under Irrigated Conditions", Journal of Hydrology, Volume 71, pp. 165-179, 1984.

[14] Singh, J., and Kumar, R., "Integrated Water Management Model for Sirsa Irrigation Circle", Proceedings of National Seminar on Reclamation and Water Management of Water logged saline Soils", CSSRI, Karnal, India, pp. 1-21, 1994.

[15] Ministry of Irrigation, "Groundwater Estimation Methodology", Report of the Ground Water Estimation Committee, Ministry of Irrigation, pp. 39, Government of India, New Delhi, 1984. 